\title{
Biomass Stand-Alone System for Power Supply Option to Remote/Isolated Locations
}

\author{
Boniface Onyemaechi Anyaka, Uche Chinweoke Ogbuefi, Mbunwe Muncho Josephine, \\ Kenneth Chijioke Chike, Prince Anthony Okoro
}

\begin{abstract}
Reliability and continuity of electricity supply generated by the use of fossil fuels cannot be guaranteed absolutely because of the present decline in oil and gas. Because of this, it becomes necessary to consider another form of energy generation such as biomass. In this work, the potential of electricity generation for a small household rural/isolated location using combustion technique was done. Due to the availability of sufficient biomass (agricultural waste) in rural/isolated locations, rice husk combustion technique for biopower generation was investigated in this work. The experiment was conducted at Uburu in Ohaozara Local Government Area of Ebonyi State. A $12 \mathrm{~V}$ permanent magnet DC motor was used as the alternator while rice husk was used as biomass fuel. The biopower was achieved by heating water to steam which was used to turn the turbine attached to the permanent DC motor and a maximum of 155Whr was generated. From the result, it can be seen that the typical load of a household in a rural/isolated location is $55 \mathrm{~W}$ and the peak experimental power is $154.96 \mathrm{~W}$. This peak experimental power is sufficient to carry the household load in a rural/isolated location. The peak experimental energy value is $1549.6 \mathrm{Whr}$ in a 10 minutes interval which is far more than the energy demand of $260 \mathrm{Whr}$ in a typical household in rural/isolated location. The result shows that biomass can be used to generate power for lighting point and power outlet for small households in rural/isolated locations.
\end{abstract}

Index Terms: Rice husk, power generation, rural/isolated locations, permanent magnet DC motor.

\section{INTRODUCTION}

Electric power supply in most cities of the world is epileptic and there is lack of it in rural communities [1]. This has being the greatest challenge confronting the economy of most nations. National power grid of most countries is insufficient to serve the cities let alone extending it to rural dwellers. Ironically, most agricultural activities are concentrated in the rural areas. This lack of power supply in rural areas has led to lack of basic amenities; thus, leading to rural-urban migration [1].

Revised Manuscript Received on February 05, 2020.

* Correspondence Author

B.O. Anyaka*, Department of Electrical Engineering, University of Nigeria, Nsukka, Enugu State, Nigeria (boniface.anyaka@unn.edu.ng)

U.C. Ogbuefi, Department of Electrical Engineering, University of Nigeria, Nsukka, Enugu State, Corresponding author: (uche.ogbuefi@unn.edu.ng)

M.J. Mbunwe, Department of Electrical Engineering, University of Nigeria, Nsukka, Enugu State. Corresponding author: (muncho.mbunwe@unn.edu.ng)

K. C. Chike, Department, University of Nigeria, Nsukka, Post graduate hall residence, Nsukka (kennethshari34@gmail.com).

P. A. Okoro, Department of Electrical Engineering, University of Nigeria, Nsukka, Enugu State, Nigeria (prince.okoro@atbebeque.com).

(C) The Authors. Published by Blue Eyes Intelligence Engineering and Sciences Publication (BEIESP). This is an open access article under the CC BY-NC-ND license (http://creativecommons.org/licenses/by-nc-nd/4.0/)
Lack of electricity access in rural part of the world is a huge challenge due to the high transmission and distribution cost [2]. To diversify the economy of any nation, greater attention should be paid to

Power sector [3]. Constant power supply in rural, commercial and industrial sites will boost: performance, productivity, efficiency, profit and reduce lost time [3]. The demand for constant power supply is ever increasing; however, the demand is met with lot of constraints [4]. These constraints include over dependency in petrol, diesel and hydro energies for firing power plants [5, 6].The major means of power generation are hydro and thermal [8]. Hydro energy is seasonal as the output power during dry season decreases noticeably whereas thermal plants depend on petrol and diesel that are not economical to produce and discharges dangerous gases during operation [4]. Currently; more than 1.5 billion people worldwide are out of power supply. $80 \%$ of this population leave in rural areas and have no hope of gaining access to electricity in the near future [2].

International Energy Agency projected that the population without access to electricity will not drop owing to population growth [7]. The rural/isolated dwellers should not be allowed to stay in darkness, remedy must be found as they are mostly agricultural sites. The remedy to this challenge is employing these four basic technical approaches: The first alternative is extending the national grid. Extending the national grid is expensive because rural areas are located far from the grid network. The high cost associated with extending the transmission lines usually makes these projects unfeasible [2]. However; cost of grid extension differ from rural locations to rural locations [8], in most of them, grid extension is feasible only at a certain distance and as long as the village has a large demand to reach critical mass [9]. This makes the national gird extension not to be feasible. The second alternative is electricity Hybrid-Mini-Off-Grid Power Supply Option $[10,11]$. This technology involves combination of different primary sources of energy (solar, biomass, wind, hydro, etc.) and generator sets for power generation [12]. This technology has potential to provide centralized electricity to rural/isolated dwellers, using a village-wide distribution network [13]. It can supply power to both domestic appliances and local businesses, and has the potential to solve the problem of energy poverty in rural/isolated areas [14]. But the high cost and technicalities involved in deploying Hybrid-Mini-Off-Grid power system is very challenging [15]. 
Also the complex business models, maintenance and sustainable operations make this option to be partly unfeasible [16]. The third alternative is Energy Home System (EHS). The selection of this technology depends mainly on the position of the households, and the types of load required. A village can support the installation of its own small power system [17-21], but the distribution costs represent a big share of the project and its feasibility. Thus; rural/isolated locations with scattered population, covering a large area will involve higher connection costs, due to longer distribution lines [22]. This makes this option not to be feasible for scattered populated villages. The fourth alternative is Stand-Alone System (SAS). A Stand-Alone Small-To-Medium-Sized Systems Power Supply Option is the best solution in bringing power to remote/isolated sites as it is economical and feasible. Stand-Alone Systems such as: Pico-Biomass System (PBS), Pico-Hydro Systems (PHS), Solar Home System (SHS) and Wind Home System (WHS), etc are the solution to provide energy access to remote/isolated households. In these stand-alone systems, the power generation is installed close to the load and there are no transmission and distribution costs and energy loss. This alternative is mainly to serve small appliances for lighting and communication (radios, mobile phone charging, TVs). Renewable sources for SAS are easily available at no cost but PBS gives better availability and low capital cost when compared to other sources since its availability is not affected by weather variation and the technology for the conversion of PBS is relatively cheap. This work takes a look at application of biomass as energy source for standalone power generation to rural/isolated dwellers. The biomass feedstock that was used is rice husk.

\section{A. Technologies to convert rice husk to energy}

Rice husk can be converted into energy products through two processes: bio-chemical processand thermo-chemical process.

\section{B. Bio-chemical process}

There 2 main techniques used here - anaerobic digestion and fermentation. In aerobic digestion technique, microorganisms convert the rice husk into Synthetic Natural Gas (SNG) [23]. This biogas can be used as fuel to generate heat and energy [24]. Rice husk takes longer time to decay; this makes this method not to be a good option for energy generation using rice husk feed stock. In fermentation process, the rice husk is converted to ethanol [25]. This option is not for power generation and it takes a lot of time for rice husk to ferment, thus; making this technique not to be the best option.

\section{Thermo-chemical process}

There are 3 main techniques used in this process, namely:pyrolysis, gasification, direct combustion techniques [26]. The first technique is the so called pyrolysis technique. It involves controlled heating of rice husk in absent of oxygen [27]. It can be slow pyrolysis in the case of low temperature $\left(350^{\circ} \mathrm{C}\right.$ to $\left.700^{\circ} \mathrm{C}\right)$ or fast pyrolysis in the case of high temperature $\left(700^{\circ} \mathrm{C}\right.$ to $\left.1050^{\circ} \mathrm{C}\right)$ [28]. This technique produces more of bio-oil than biogas [29] and the technology is expensive [27]. It also produces large quantity of char which is not desirable [27]. This process involves a lot of gas and oil filtration, scrubbing and cleaning. This makes the initial cost of this technique to be high. Most of the rural dwellers may not be able to provide the installation cost, thus; making this technology not the best option for rural dwellers. The second technique is by gasification technology. During gasification process, rice husk is directly converted to producer gases, char, tar, impurities from sulphur and nitrogen in a gasifier at a very high temperature (more than $1050^{\circ} \mathrm{C}$ ) under a controlled amount of air or steam [28]. This technique involves suphiscated conversions, thus; making the installation cost to be high which may not be affordable by the rural dwellers [3031].Direct combustion technique involves burning of rice husk to produce heat which will be use to heat water to steam and the steam will be used to drive steam turbine [32]. This technique is economical and can be achieved by the use of locally sourced material, thus; making this technique to be the best option for rural/isolated dwellers. Among all these techniques discussed above, it is obvious that direct combustion technique is an excellent option for rice husk standalone power supply option. This work will center on rice husk direct combustion local technology for electricity generation. The block diagram of the process is as shown in Figure 1.

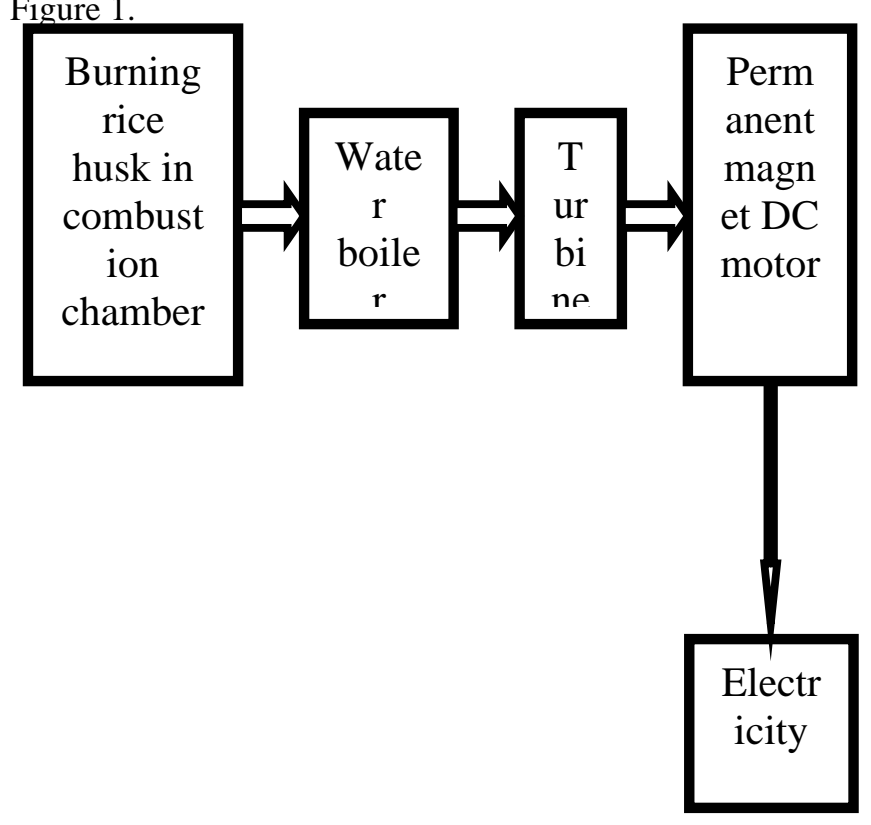

Figure 1. Block diagram of electricity generation by rice husk using combustion technique.

The experiment was carried out at Uburu in Ohaozara Local Government Area of Ebonyi state, Nigeria. Rice husk obtained from AkpaNwaokorori's farm in Amenu rice mill of Ohaozara Local Government Area of Ebonyi state, Nigeria was used as energy source. Combustion chamber, boiler unit and turbine constructed from locally available materials were used for the work. Permanent magnet DC motor was used as the alternator to generate the DC power. These are shown in Figures 2 to 4 . The work will benefit dwellers in rural/isolated locations as they will use it for lighting point and power outlet for powering their electrical appliances; thus, providing basic social amenities which in turn minimizes rural-urban migration. It will also reduce over burden on electricity providers. 

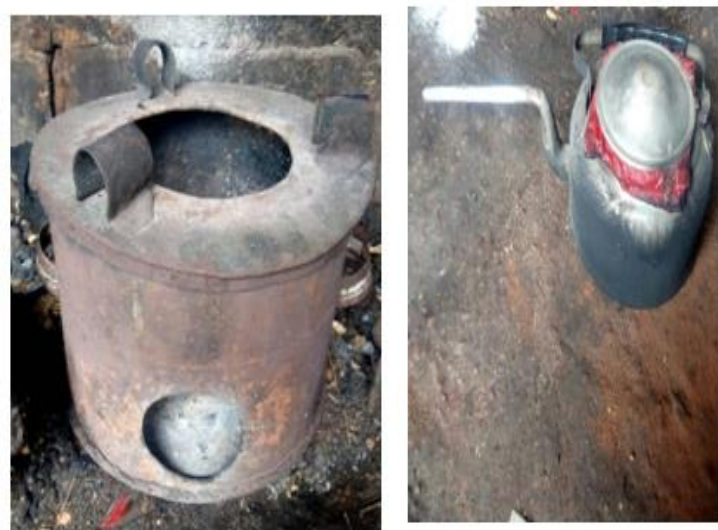

Figure 2. Combustion chamber

Figure 3. Water boiler

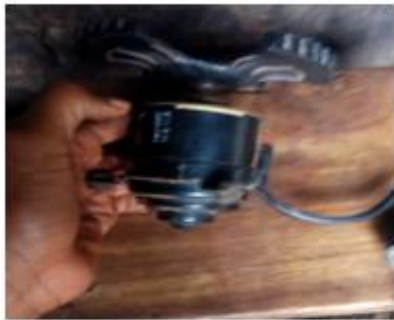

Figure 4. DC motor coupled with turbine

\section{LITERATURE REVIEW}

In this section, we shall review some works on rice husk combustion technique for electricity generation. The purpose of this literature review is to identify the knowledge gap that justify this work and also for referencing. Thipwimon et al [33], conducted an assessment on rice husk combustion for power production. A $10 \mathrm{MW}$ pilot plant using rice husk as feedstock was used for the study. The environmental impacts from rice husk power plant were evaluated by using the Life Cycle Assessment (LCA) methodology. Energy, material and carbon balances were determined for tracing the system flow. Carbon closure was used for describing the net amount of carbon (iv) oxide $\left(\mathrm{CO}_{2}\right)$ released from the system in relation to the amount being recycled between the power plant and the $\mathrm{CO}_{2}$ adsorbed by rice husk. The results showed that the impact potentials from rice husk power plant are lesser than the conventional plants for most of the categories considered. This is the case of EHS that will suffer from high implementation cost this may not be feasible in many rural location as a result of distribution and maintenance cost. Memon at al [34], conducted an assessment on resource potential of rice husk generated in the rice mill. They also carried out technical and economic evaluation of rice husk based $1 \mathrm{MW}$ fluidized bed combustion (FBC) power plant. It was estimated that through the FBC power plant, annual electricity of $5360 \mathrm{MWh}$ can be generated with rice husk fuel consumption of 6968 tons; cost of generating electricity through FBC was approximately Rs.4/kWh This is the case of EHS that will suffer from high implementation cost this may not be feasible in many rural location as a result of distribution and maintenance cost. Muhammad et al [35], conducted a study to determine the potential of electrical energy of rice husk as fuel for power generation in Indonesia. The estimated potential of rice husk in each province of the country was calculated using the statistical data of rice production from 2011. The estimated annual potential of rice husk development was calculated using statistical data from 2001 to 2012. The results indicate that the development potential of rice husk, potential for electrical energy and economic potential increased by approximately $36.8 \%$ over 12 years; an average of about $3.1 \%$ per year. In 2011, the 33 provinces had rice husk potential of around 10.52 million tons, which is equivalent to about 5.24 million tons of coals, provided electrical energy and electrical power potentials of about 39,272 GWh and 4, $481 \mathrm{MW}$, respectively. About 26 provinces had potential of rice husk for electrical energy greater than 100 GWh, providing a total electrical energy potential of approximately 39,076 GWh, and electrical power of around 4, $460 \mathrm{MW}$. This is the case of EHS that will suffer from high implementation cost this may not be feasible in many rural location as a result of distribution and maintenance cost. Jenkins et al [36], investigated the financial feasibility if utilising leached rice husk as fuel for existing biomass boiler, using rice husk combustion technique. Their finding shows that rice husk combustion technical shows a good financial feasibility when used as a fuel. This is the case of EHS that will suffer from high implementation cost this may not be feasible in many rural location as a result of distribution and maintenance cost. Bakker et al [37], demonstrated that leached rice husk can be utilised as fuel in fluidised bed combustion. Their finding shows that by pretreating the rice husk with leached process, rapid and undesirable ash deposition generally associated with untreated rice straw will be reduced. This is the case of EHS that will suffer from high implementation cost this may not be feasible in many rural location as a result of distribution and maintenance cost. Permchart et al [38], reported the result of combustion performance of various biomass fuels, such as: sawdust, rice husk and pre-dried sugar cane bagasse, in a fluidised bed combustor. Rice husk shows the best performance in power production and less environmental damages. This is the case of EHS that will suffer from high implementation cost this may not be feasible in many rural location as a result of distribution and maintenance cost. Okasha[39], investigated the efficiency of staged combustion in fluidised bed for rice husk to reduce NOx emissions, in particular, at high combustion temperatures. From their findings, at a high temperature, NOx emission was reduced. This is the case of EHS that will suffer from high implementation cost this may not be feasible in many rural location as a result of distribution and maintenance cost. Madhiyanon et al [40], studied the combustion performance of co-firing rice husk with bituminous coal in a cyclonic fluidised bed combustor with capacity of $120 \mathrm{~kW}$, along with the effects of fuel blends excess air ratio and fuel blend to combustion efficiency and emission. 
From their findings, co-firing of rice husk with excess air gives better result and reduces the effect of $\mathrm{CO}_{2}$ on the environment. This is the case of EHS that will suffer from high implementation cost this may not be feasible in many rural location as a result of distribution and maintenance cost. Sathitruangsak et al [41] studied the combustion performance of co-firing rice husk with coal in a fluidisedbed combustor with a short combustion chamber. From their results, co-firing of rice husk reduces the environmental effects of $\mathrm{CO}_{2}$. The potential of rice husk for power generation, productive use of electricity and load assessment of the study area were not considered.

Owing to the drawback in the works of [33 - 41] a PBS was designed and used to supply power to rural/isolated dwellers in Amenu, Uburu, Ohaozara Local Government Area of Ebonyi state, Nigeria.

\section{EXPERIMENTAL PROCEDURES AND RESULT DISCUSSIONS}

We have considered block diagram of Figure 1 in the implementation of this work. The typical load for this standalone power supply option is as shown in Table 1.

Table 1: Typical load for an isolated location

\begin{tabular}{|l|l|l|l|l|l|}
\hline S/N & Load & $\begin{array}{l}\text { No. } \\
\text { in } \\
\text { use }\end{array}$ & $\begin{array}{l}\text { Power } \\
\text { (Watts) }\end{array}$ & Hrs/Day & $\begin{array}{l}\text { Watt- } \\
\text { hrs/Day }\end{array}$ \\
\hline 1 & $\begin{array}{l}\text { Low- } \\
\text { energy DC } \\
\text { lights }\end{array}$ & 4 & 5 & 5 & 100 \\
\hline 2 & Radio & 1 & 10 & 6 & 60 \\
\hline 3 & $\begin{array}{l}\text { DC ceiling } \\
\text { fan }\end{array}$ & 1 & 15 & 4 & 60 \\
\hline 4 & $\begin{array}{l}\text { DC } \\
\text { standing } \\
\text { fan }\end{array}$ & 1 & 10 & 4 & 40 \\
\hline 5 & Total & & $\mathbf{5 5}$ & & $\mathbf{2 6 0}$ \\
\hline
\end{tabular}

A bottle was placed at the center of the locally constructed combustion chamber as shown in Figure 5. Rice husk of $7 \mathrm{~kg}$ used as the fuel was divided into three places $(3 \mathrm{~kg}, 3 \mathrm{~kg}$, and $1 \mathrm{~kg})$. The first $3 \mathrm{~kg}$ was gradually poured into the combustion chamber as shown in Figure 6 and was compressed with feet in order to make it strongly compacted as shown in Figure 7. The bottle placed at the center of the combustion chamber was pulled up in order to come out of the compressed $3 \mathrm{~kg}$ rice husk. Additional 3kg was added at this point, compressed and the bottle pulled up again. The remaining $1 \mathrm{~kg}$ was finally added, compressed and the bottle was finally brought out. The purpose of putting the bottle is to create cavity at the middle of the combustion chamber as shown in Figure 8a. After preparing the combustion chamber for operation, the boiling unit, the permanent magnet DC motor coupled with turbine, the voltmeter and ammeter were positioned as shown in Figure 9. The combustion chamber was lighted up and the experiment commenced. The voltmeter was connected in parallel while the ammeter was connected in series to the output of the permanent magnet DC motor. At 100 degrees centigrade, the water started boiling and steam produced. The steam produced at this point was used to drive the turbine attached to the permanent magnet DC motor. When the turbine

started rotating, the permanent magnet DC motor started producing power. The output cable of the motor was extended for convenience purpose in order to take readings at ten minutes interval. Obtained output DC voltage, DC current and calculated DC watthour are as presented in Table 2 .

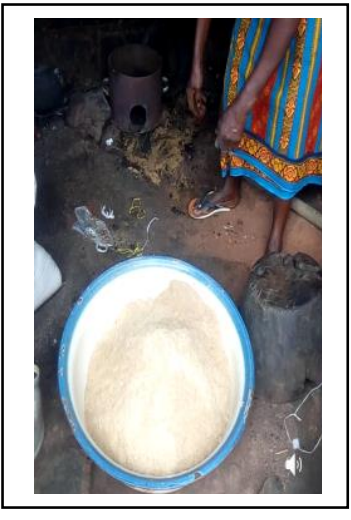

Figure $5.7 \mathrm{~kg}$ rice husk

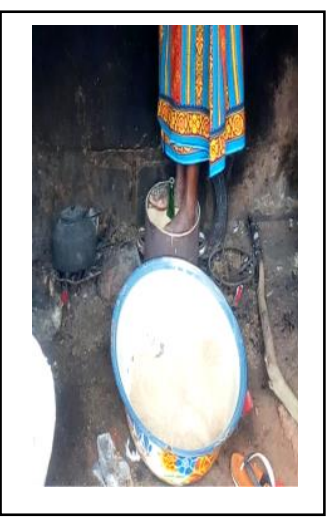

Figure 7. Compression of Figure 8a. Compressed 7kg $3 \mathrm{~kg}$ and $1 \mathrm{~kg}$ rice husk in the combustion chamber

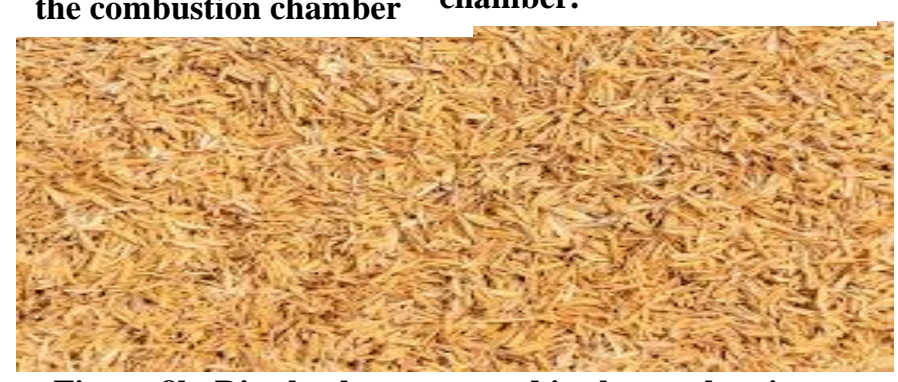

Figure 8b. Rice husk compressed in the combustion chamber

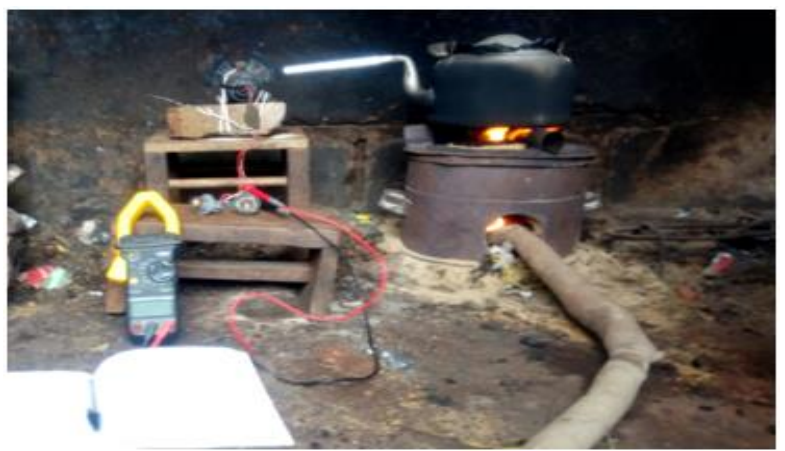

Figure $9.7 \mathrm{~kg}$ rice husk

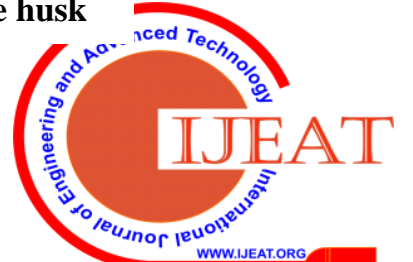


Table 2: Results showing DC voltage, DC current and calculated DC watthour.

\begin{tabular}{|l|l|l|l|l|l|l|}
\hline $\begin{array}{l}\text { Time(minut } \\
\text { es) }\end{array}$ & 10 & 20 & 30 & 40 & 50 & 60 \\
\hline $\begin{array}{l}\text { DC Voltage } \\
\text { (V) }\end{array}$ & 0.00 & 1.88 & 3.33 & 4.67 & 5.88 & $\begin{array}{l}6.2 \\
4\end{array}$ \\
\hline $\begin{array}{l}\text { DC Current } \\
\text { (A) }\end{array}$ & 0.00 & 0.22 & 0.52 & 0.94 & 1.22 & $\begin{array}{l}1.8 \\
7\end{array}$ \\
\hline $\begin{array}{l}\text { DC Power } \\
\text { (W) }\end{array}$ & 0.00 & 0.138 & 0.86 & 2.93 & 5.978 & $\begin{array}{l}11 . \\
669\end{array}$ \\
\hline $\begin{array}{l}\text { DC Power } \\
\text { (Whr.) }\end{array}$ & 0.00 & 1.38 & 8.65 & 29.3 & 59.78 & $\begin{array}{l}116 \\
.69\end{array}$ \\
\hline $\begin{array}{l}\text { Time(minut } \\
\text { es) }\end{array}$ & 70 & 80 & 90 & 100 & 110 & 120 \\
\hline $\begin{array}{l}\text { DC Voltage } \\
\text { (V) }\end{array}$ & 8.32 & 11.70 & 12.1 & 12.7 & 14.02 & $\begin{array}{l}15 . \\
91\end{array}$ \\
\hline $\begin{array}{l}\text { DC Current } \\
\text { (A) }\end{array}$ & 2.10 & 3.77 & 3.97 & 4.12 & 4.43 & $\begin{array}{l}4.8 \\
7\end{array}$ \\
\hline $\begin{array}{l}\text { DC Power } \\
\text { (W) }\end{array}$ & 20.3 & 58.81 & 74.6 & $\begin{array}{l}87.4 \\
1\end{array}$ & $\begin{array}{l}113.8 \\
7\end{array}$ & $\begin{array}{l}154 \\
.96\end{array}$ \\
\hline $\begin{array}{l}\text { DC Power } \\
\text { (Whr.) }\end{array}$ & 203. & 588.1 & 746. & 874. & 1138. & 154 \\
7 & 0 & 2 & 1 & 7.6 \\
\hline
\end{tabular}

As seen in Table 2, the experiment lasted for 2hours. In the first 10 minutes, the voltage, current and power was zero respectively because the turbine has not started rotating. But, from 20 minutes and beyond, the turbine stated rotating and the permanent magnet motor started generating power. Measurement of DC voltage and DC current were done at 10 minutes interval and their corresponding DC watt hours were calculated. The voltage and current increased as the time increased. Also, the calculated power and watt hour increased with the increased in voltage and current. The peak power is $154.96 \mathrm{~W}$ while the peak watt-hour is 1549.6Whr. The typical load and energy demand of a household in rural/isolated area is compared with the peak power and peak energy generated during the experiment is as shown in Figure 10.

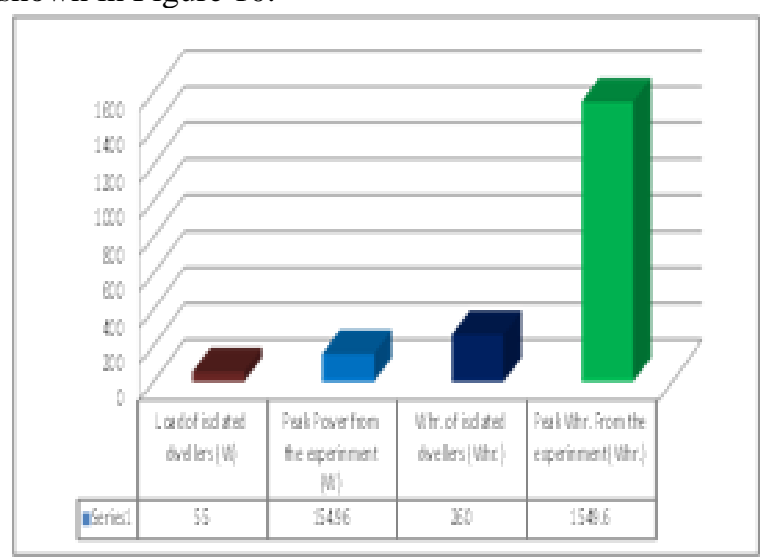

Figure 10: Comparison of rural household standalone load with the experimental values.

From Figure 10, it can be seen that the typical load of a household in a rural/isolated location is $55 \mathrm{~W}$ and the peak experimental power is $154.96 \mathrm{~W}$. This peak experimental power is sufficient to carry the household load in a rural/isolated location. The peak experimental energy value is $1549.6 \mathrm{Whr}$ in a 10 minutes interval which is far more than the energy demand of 260Whr in a typical household in rural/isolated location. The cost of the work is shown in Table 3.

Table 3: Cost of the locally sourced materials

\begin{tabular}{|l|l|l|}
\hline S/N & Device & Price(N) \\
\hline 1 & Permanent Magnet DC Motor & 5,000 \\
\hline 2 & Combustion Unit & 1,500 \\
\hline 3 & Boiler Unit & 2,000 \\
\hline 4 & Construction work & 2,000 \\
\hline 5 & Total & $\mathbf{1 0 , 5 0 0}$ \\
\hline
\end{tabular}

\section{CONCLUSION}

The conversion of biomass into electricity has been proven economically and viable especially for rural/isolated community applications in developing countries. PBS presents a very viable option for rural/isolated locations because biomass is abundantly available in the location and its power conversion can be done through local technologies. In this work, the analysis and experimental backup of biomass power generation was done. The experimental backup was implemented by combustion technique using local technology. The experiment was conducted for two hours. A $12 \mathrm{~V}$ permanent magnet DC motor was used as the alternator while rice husk was used as fuel. The bio-power was achieved by heating water to steam which was used to drive the turbine attached to the permanent DC motor and 155Whr DC power was achieved. From the result, it can be seen that the typical load of a household in a rural/isolated location is $55 \mathrm{~W}$ and the peak experimental power is $154.96 \mathrm{~W}$. This peak experimental power is sufficient to carry the household load in a rural/isolated location. The peak experimental energy value is $1549.6 \mathrm{Whr}$ in a 10 minutes interval which is far more than the energy demand of 260Whr in a typical household in rural/isolated location.

\section{REFERENCES}

1. H. Rahman et all, "Designing of Biomass Based Power Plant for Residential Building Energy System", Proc. Of International Conference on Electrical Engineering and Information Communication Technology (ICEEICT) Dhaka, pp. 1 -6, 2015. [Accessed on $25^{\text {th }}$ July, 2018].

2. C. J Obetta, "Design of $33 \mathrm{KV} / 415 \mathrm{~V} / 230 \mathrm{~V} 50 \mathrm{HZ}$ Three Phase Distribution Network of UmunduTown, Undergraduate Project, University of Nigeria, Nsukka, pp 41 \& 42, $\quad 2010$ [Unpublished].

3. P. Meisen and I. Akin, "The case of meeting the Millennium Development Goals through access to clean Electricity",2008.Avaliablehttp://www.geni.org/globalenergy/research /meeting-mdgs-through-access-to-electricity/MDG_Final_1208.pdf [Accessed: Jan. 2019].

4. L. Cutz et all, "Assessment of Biomass Energy Sources and Technologies: The case of central America", Renewable and Sustainable Energy Reviews, vol. 58, pp 1411- 1431, May 2016. [Accessed on $25^{\text {th }}$ July, 2018].

5. A. C. Ohajianya, O. E. Abumere, I. O. Owate and E. Osarolube, "Erratic power supply in Nigeria: causes and solutions", International Journal of Engineering Science Invention, vol. 3 Issue 7, pp. 51-55, Jul. 2014.

6. D. P. Kaundinya, P. Balachandra and N.H. Ravindranath, "Gridconnected versus stand-alone energy systems for decentralized power - A review of literature", Renewable and Sustainable Energy Reviews, pp. 2041 - 20150, Feb. 2009.

7. USAID, "Hybrid Mini off grids for rural elicitation: Lessons learned", Alliance for Rural electrification, Renewable Energy House Rue d'Arlon 63-65 1040 Brussels Belgium. 
8. M. Moner-Girona et al, "Electrification of Sub-Saharan Africa through PV/hybrid mini-grids: reducing the gap between current business models and on-site experience", Renewable and Sustainable Energy Reviews, pp. 1148 - 1161, Apr. 2018.

9. S.A. Oyejide, I.A. Adejumobi, S.T. Wara and E.S.A. Ajisegiri, "Development of a grid-based rural electrification design: A case study of Ishashi and Ilogbocommunities in Lagos state, south western Nigeria", IOSR Journal of Electrical and Electronics Engineering (IOSR-JEEE), vol. 9, $\quad$ issue 4, pp. 12 - 21, Jul. 2014.

10. K.A. Glaisa, M.E. Elayeb and M.A. Shetwan, "Potential of Hybrid system powering school in Libya", Renewable and Sustainable Energy Reviews, pp. 1411 - 1420, Oct. 2018.

11. S.K. Nandi and H.R. Ghosh, "A wind-PV-battery hybrid power system at Sitakunda in Bangladesh", Energy Policy, pp. 3659 - 3664, Apr. 2009.

12. A.M. Patel and S.K. Singal, "Off grid rural electrification using integrated renewable energy system”, 2016 IEEE 7th Power India International Conference (PIICON), pp. 253 259, Oct. 2017.

13. S. U. Rehman et al, "Feasibility study of hybrid energy system for off-grid rural electrification in southern Parkistan", Energy Exploration and Exploitation, pp. 1 - 15, 2016.

14. T. Urmee, H. David and S. August, "Issues related to rural electrification using renewable energy in developing countries of Asia and Pacific", Renewable and Sustainable Energy Reviews, pp. 354 - 357, May 2008.

15. W.K. Biswas, D. Mark and B. Paul, "Can photovoltaic technologies help attain sustainable rural development in Bangladesh" Energy Policy, pp. 1199 - 1207, Mar. 2004.

16. U. S. Akpan and Y. N. Udoakah, "Electricity access in Nigeria: Viability of off-grid photovoltaic system",

AFRICON 2013: IEEE African Conference: Sustainable engineering for a better future, pp. 473 - 479, Sept. 2013.

17. B.O. Anyaka and C.I. Imaeka, "Small Hydropower Projects for Rural Electrification in Nigeria: A Developer's Perspective," International Journal of Innovative Technology and Exploring Engineering (IJITEE), vol. 3, pp. 29 - 35, Oct. 2013

[Accessed on $25^{\text {th }}$ July, 2018].

18. C.ANwoso and T.C Madueme, "Recycled Micro Hydropower Generation Using Hydraulic Ram Pump (HYDRAM), IMPACT: International Journal of Research inEngineering \& Technology (IMPACT: IJRET, vol. 1, pp. 1 - 10, Aug. 2013 [Accessed on $25^{\text {th }}$ July, 2018].

19. B.O. Anyaka and E.O. Nwokolo, "Solar Cells Technology: An Engine for National Development," IOSR Journal of Electrical and Electronics Engineering (IOSR JEEE), vol. 7, pp. 13 - 18, Oct. 2013. [Accessed on 25 ${ }^{\text {th }}$ July, 2018].

20. O.I Okoro and T.C Madueme, "Solar Energy: A Necessary Investment in a Developing Economy," Nigerian Journal of Technology, vol. 23, pp. 58 - 64, March 2004. [Accessed on $25^{\text {th }}$ July, 2018].

21. B.O. Anyaka and U.O. Orji, "Increasing the Efficiency of the Grid System using Renewable Energy" IOSR Journal of Electrical and Electronics Engineering (IOSR-JEEE), vol. 9, pp. 35 - 42, May. 2014. [Accessed on $25^{\text {th }}$ July, 2018].

22. R. Sankar, P.K.A. Jery and S. Sreevas, "A study on low cost electrification using solar energy a field work",

International Journal of Computer Theory and Engineering, vol. 4, no. 6, pp. 1015 - 1019, Dec. 2012.

23. I. Angelidaki and D.J. Batstone, "Anaerobic digestion: process Solid waste technology and management", John Wiley \& Sons, Ltd., pp. $583-600,2010$

24. D.J. Hills and D.W. Roberts, "Anaerobic digestion of dairy manure and field crop residues", Agricultural Wastes, pp. 179-189, 1981.

25. M.J. Taherzadeh and C. Niklasson, "Ethanol from lignocellulosic materials: pre- treatment, acid and enzymatic hydrolyses and fermentation", ACS Publications;pp. 49 - 68, 2004.

26. H. Goyal, D. Seal and R. Saxena, "Bio-fuels from thermo-chemical conversion of renewable resources: a review", Renewable and Sustainable Energy Reviews, pp. 504 - 517, Dec., 2008.

27. M.N. Islam and F.N. Ani, "Techno-economics of rice husk pyrolysis, conversion with catalytic treatment to produce liquid fuel", Journal of Bio Resource Technology, pp.67 - 75, 2000.

28. Solar Energy Research Institute, "Handbook of Biomass Downdraft Gasifier Engine Systems", Department of Energy Solar Technical Information Program, U.S.A., Mar., 1988.

29. S.R. Tewfik et al, "Bio-oil from rice straw by pyrolysis: experimental and techno-economic investigations", Journal of America Science, pp. $1-7,2011$.
30. T. Kapur, T.C. Kandpal and H.P. Garg, "Electricity generation from rice husk in Indian rice mills: potential and financial viability", Biomass Bioenergy, pp. 393 - 403, Oct., 1996.

31. H. Abe et al, "Potential for rural electrification based on biomass gasification in Cambodia", Biomass Bioenergy, pp. 643 - 656 2007.

32. P. Wibulswas, S. Panyawee and A. Terdyothin, "Potential for power generation in alarge white rice mill”, Renew Energy, pp. 796 - 808 May, 1994.

33. T. Chungsangunsit, S.H. Gheewala, S. Patumsawad, "Emission Assessment of Rice Husk Combustion for Power Production", International Journal of Energy and Environmental Engineering, vol.3, no:5, pp. 625 - 630, 2009

34. T. A. Memon et al, "Potential of Electricity Generation from Rice Husk-A Case Study of Rice Mill", Sindh University Research Journal (Science Series), vol.49, no. 3, pp. 495 498, 2017.

35. M. Anshar1, F. N. Ani and A. S. Kader, "Electrical energy potential of rice husk as fuel for power generation in Indonesia", ARPN Journal of Engineering and Applied Sciences, vol. 11, no. 6, Mar. 2016.

36. B. Jenkins et al, "Commercial feasibility of utilizing rice straw in power generation", Proceedings of Bioenergy, Buffalo, New York, pp. 256 - 263, 2000.

37. R.R. Bakker, B.M. Jenkins and R.B. Williams, "Fluidized bed combustion of leached rice straw", Energy Fuels, pp. 356-365, 2002.

38. D. Albina, "Combustion of rice husk in a multiple-spouted fluidized bed", Renewable Energy, pp. 893-904, 2003.

39. Okasha F, "Staged combustion of rice straw in a fluidized bed", Experimental Thermal and Fluid $\quad$ Science, pp. 52 - 9, 2007.

40. T. Madhiyanon, P. Sathitruangsak and S. Soponronnarit, "Cocombustion of rice husk with coal in a cyclonic fluidized-bed combustor" Fuel, pp. 132-138, 2009.

41. P. Sathitruangsak, T. Madhiyanon and S. Soponronnarit, "Rice husk co-firing with coal in a short-combustion-chamber fluidized-bed combustor (SFBC)", Fuel, pp.1394-402, 2009.

\section{AUTHORS PROFILE}

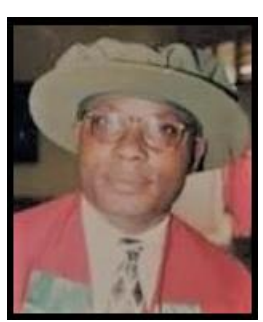

Boniface Onyemaechi Anyaka is currently a Senior Lecturer in the Department of Electrical Engineering, Faculty of Engineering, University of Nigeria, Nsukka, Nigeria. He had his M.Eng in Electric Power System/Applied Automatics from the University of Technology, Wroclaw, Poland in 1988 and his Ph.D. from the Department of Electrical Engineering. University of Nigeria, Nsukka in 2011.He was the acting Head, Department of Electrical Engineering, University of Nigeria, Nsukka (2011-2013) andAssociate Dean, Faculty of Engineering, University of Nigeria, Nsukka (2016-2018). His major field of research include: power system modelling and renewable energy (Photovoltaic). He has to his credit, over 50 publications in both local and international journals.

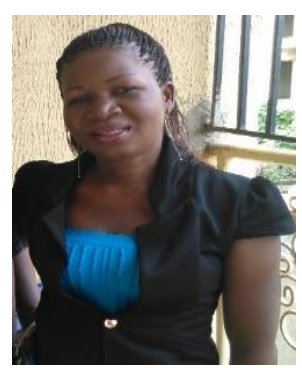

Dr. Uche. C. Ogbuefi major in Electrical Power Systems. She obtained her Doctorate Degree in Electrical Engineering from University of Nigeria, Nsukka in 2013. She worked with many companies before she joined the academic world as a Lecture in the Department of Electrical Engineering, University of Nigeria, Nsukka. She is a corporate member of the Nigeria Society of Engineers (NSE), and COREN registered. Member Association of Professional Women in Engineering (APWEN). Member International Association of Engineers (IAENG). She has published in both local and international journals and conference proceedings. Her research interes includes Power Systems Optimization, and Renewable Energy Technology. 


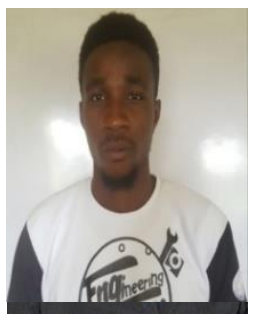

MbunweMuncho Josephine had her (B.Eng) and (M. Eng) degrees in Electric Power Systems in 2000 and 2005 respectively from the University of Nigeria, Nsukka. She is a lecturer in the department of Electrical Engineering, University of Nigeria, Nsukka. A Corporate member of Nigeria Society of Engineers (NSE) 2009 and member Council for the Regulation of Engineering in Nigeria (COREN) 2014. Her research interests include embedded generation of renewable and non-renewable energy systems. She worked as site Engineer for Rural Electrification projects in Enugu and Anambra States of Nigeria. She has published papers in some journals and in conference proceedings.

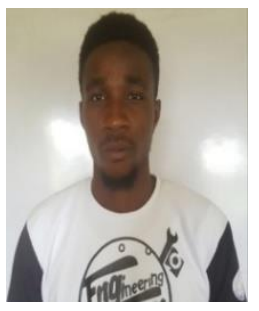

Kenneth ChijiokeChike received his bachelor degree in Electrical and Electronics Engineering (B.Eng) from Igbinedion University, Okada, Nigeria. He is currently a masters Engineering student in the Department of Electrical Engineering, University of Nigeria, Nsukka. His Research area interest is in Power Systems Engineering and Renewable Energy.

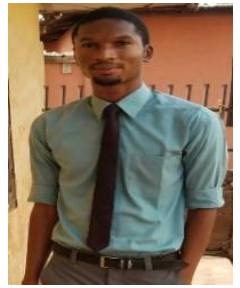

Prince Anthony Okoro received his bachelor degree in Electrical Engineering from the Department of Electrical engineering, University of Nigeria, Nsukka. He is currently a masters Engineering student in the Department of Electrical Engineering, University of Nigeria, Nsukka. He is an EnergyNet Student, 2019. He is a cofounder of BEBEQUE LEMITED. His area of interest is in Power Systems Engineering and Green Power Generation through Renewable Energy.

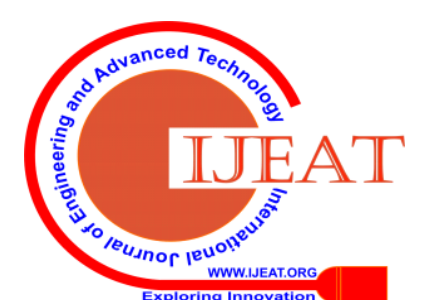

